\title{
Bali Cattle Cultivation in Ayunan Village Abiansemal District, Badung
}

\author{
Ni Made Ayu Gemuh Rasa Astiti ${ }^{1^{*}}$, I Wayan Wesna Astara ${ }^{1}$, I Gusti Agung Putu \\ Eryani $^{1}$ \\ ${ }^{1}$ Warmadewa University, Denpasar, 80235, Indonesia \\ *ayugemuh@gmail.com
}

Received 22-07-2021; accepted 17-09-2021

\begin{abstract}
Ayunan Village, is located in Abiansemal sub-district, Badung regency, Bali. Bali cattle are germplasm that must be preserved, for that we are collaborating with the Bali Karang Ayu and Karya laksana cattle groups in Ayunan village. The maintenance of Bali cattle in partners is very constrained by capital, feed and management of Balinese cattle maintenance is not carried out professionally because it is managed in a family, traditional way and is not a main source of livelihood. Bali cattle maintenance is only a sideline to fill spare time on the sidelines of farming time. The management of cow dung and manure has not been managed properly, which should still be managed into organic fertilizer, sold to farmers so that it can increase the income of farmers, so the solution we offer is to provide assistance and consultation as well as demonstration plots regarding good and correct management of Balinese cattle rearing. to increase Bali cattle production. The results of this community service activity can increase production, productivity as well as produce organic fertilizer from cow dung that can be sold so as to increase the income of Balinese cattle farmers in the two Bali cattle groups that we partner with.
\end{abstract}

Keywords: Bali Cattle, Ecotourism, Organic Fertilizer, Partner Group

\section{Introduction}

Ayunan Village, is located in Abiansemal sub-district, Badung regency, Bali. This village is about $20 \mathrm{~km}$ to the north from Denpasar city, to the tourist attraction village of Sangeh and Taman Ayun or about 3 kilometers from the village of Mengwi Taman Ayun, where the population is more dominant as farmers and raise Balinese cattle. The pattern of rearing Bali cattle is still traditional and as a sideline between farming time [1]. Ayunan Village has the potential to be developed as a tourism village for rearing and using Balinese cattle for plowing (traditional metekap).

Cite this as: Astiti, N.M.A.G.R, Astara, I.W.W \& Eryani, I.G.A.P (2021). Bali Cattle Cultivation in Ayunan Village Abiansemal District, Badung. Civil and Environmental Science Journal (Civense), 4(2), 202-207. doi: https://doi.org/10.21776/ub.civense.2021.00402.10 

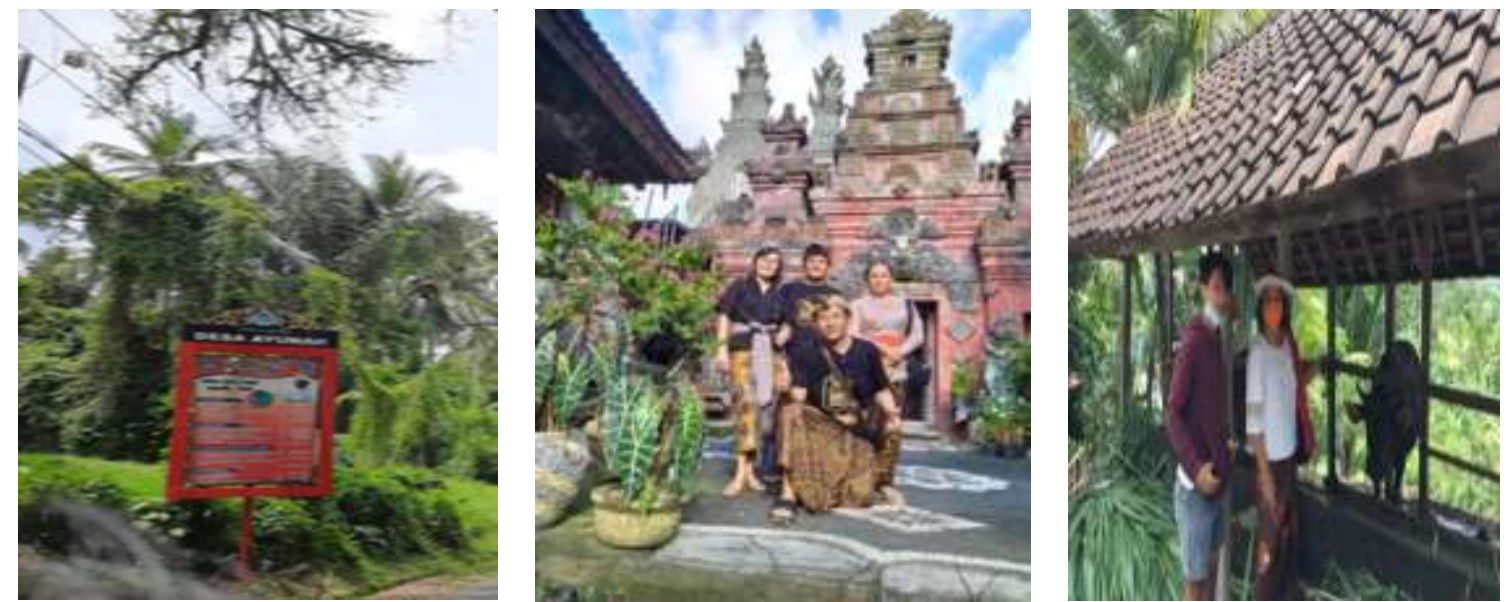

Figure 1. The atmosphere of the village of Ayunan Abiansemal Badung.

Bali cattle are germplasm that must be preserved which is supported by government policies. This is a golden opportunity for cattle breeders in Bali, because Bali is one of the sources of Bali cattle breeds and the only area that is believed to have pure Bali cattle genetics, [2]. More efficient marketing will be able to provide higher prices for farmers. Thus, a more efficient marketing system must absolutely be considered, so that cattle farms are able to provide higher additional income for farmers. This increase in income will encourage them to raise more cattle. In addition, it will encourage farmers to carry out maintenance in a better way, [3, 15].

The results of discussions with potential partners, it was found that several production distribution processes including the procurement of production facilities at partner locations can be said to have no problems. The location which tends to be close to the city center and sub-district center as well as the government's increasing attention to road infrastructure is very supportive or makes the distribution process not an obstacle. The cattle rearing management process that has occurred in the partners has taken place although it is still very simple. Planning for the production of organic fertilizer from cow dung has already taken place, but that's just the planning limit has not been implemented. Direct observations in the Karang Ayu and Karya livestock groups, such as in Ayunan village, Abiansemal district, show that partner Bali cattle rearing activities are very constrained by capital, feed, cattle rearing management, processing and manure drainage and how to increase farmers' income from Bali cattle rearing business [16].

The main problems and will be the focus of problem solving are the low management ability of Bali cattle, low productivity in processing livestock manure into organic fertilizer and low business efficiency and business sustainability of organic fertilizer products from livestock manure. The results of this activity are expected to increase production and productivity and produce organic fertilizer from cow dung that can be sold so as to increase the income of Balinese cattle farmers in Ayunan Village.

Based on observations that have been made to partner livestock groups, for the sake of their sustainability and existence it is very feasible to receive continuous guidance and assistance from higher education institutions so that they can increase the capacity, quality and income of Balinese cattle farmers through processing superior Balinese cattle products in Ayunan Village, coaching and improving management of Balinese cattle maintenance, processing of cow dung into organic fertilizer as well as marketing of organic fertilizer products and other interrelated aspects that are able to provide increased income for farmers, with increasing incomes for automatic breeders, Balinese cattle breeders will become prosperous.

\section{Materials and Methods}

The descriptive research methodology was employed in this study to describe the extent of Bali Cattle Cultivation in Ayunan Village Abiansemal District, Badung. Furthermore, descriptive research. is 
defined as study conducted for conditions or other objects and the results of which are delivered in the form of a research report. One of the descriptive research approaches that has been employed is:

a) According to [17] the survey method is a study that tries to acquire data by assessing samples from the accessible population. In the field, by observing, measuring, and recording data.

b) The interview method is a meeting of two persons to exchange information and ideas through direct question and response between the researcher and the responder, with the goal of concentrating the meaning on a certain issue [18] and obtaining in-depth data, information, and facts.

Based on the identification of the problems faced by partners and the solutions offered, the method of implementing the activities:

1. Provide assistance and consultation regarding the management of good and correct maintenance of Bali cattle to increase production of Bali cattle, both for fattening and breeding.

2. Assistance in the preparation of rations related to ration raw materials, so it is hoped that the provision of optimal rations can increase Bali cattle production.

3. Assist and practice the provision of high nutritional value animal feed so that cattle grow optimally.

4. Procurement of lawn mowers, grass holders, hoes and scops so as to speed up farmers' search for forage for livestock.

5. Counselling and assistance on the use of digital marketing.

\section{Results and Discussion.}

After conducting several meetings with partners, an agreed schedule of activities to be carried out was agreed. Partners propose several activity schedules that are tailored to their activities, so that the training does not interfere with the activities of partners. The implementation of community service activities for raising cattle properly and correctly and providing Bali Cattle Feed in partner livestock groups is carried out in several stages so that both breeders and cattle do not experience stress $[12,14]$.

Based on observations that have been made to partner livestock groups, for the sake of their sustainability and existence it is very feasible to receive continuous guidance and assistance from higher education institutions so that they can increase the capacity, quality and income of Balinese cattle farmers through processing superior Balinese cattle products in Ayunan Village, coaching and improving management of Balinese cattle maintenance, processing of cow dung into organic fertilizer as well as marketing of organic fertilizer products and other interrelated aspects that are able to provide increased income for farmers, with increasing incomes for automatic breeders, Balinese cattle breeders will become prosperous.

1. In relation to the management of partner Bali cattle breeding, it can be described the condition of each partner: Bali cattle rearing management in partners is not carried out professionally because it is managed in a family and traditional way and is not the main source of livelihood, Bali cattle rearing is only a sideline filler free time on the sidelines of farming time, which now mostly uses labor, both in land cultivation, seeding, and harvesting. Likewise, related to bookkeeping such as diaries, cash books, calculation of production costs, calculation of profit or loss are not yet available properly. Regarding HR management, it is still unclear where the division of work is not clear between one another.

2. Partners do not yet have good cattle rearing system due to limited knowledge and capabilities of farmers.

3. Management of cow dung and manure has not been managed properly, which should still be managed into organic fertilizer and sold to farmers so that it can increase the income of cattle farmers.

4. The management of cow dung and manure has not been managed properly, which should still be managed into organic fertilizer and sold to farmers so that it can increase the income of cattle farmers. 
5. The facilities owned by partners are in the form of makeshift cowsheds.

\section{Partner Problem}

1. Based on the results of observations on the two partners, there are several problems that become obstacles including: The division of work in cattle rearing is not clear because the management of cattle rearing is carried out in a modest manner and uses family workers and cattle rearing only as a sideline to fill spare time on the sidelines of farming. So, it is not the main business or livelihood of the partners.

2. Owned equipment such as a grass sickle, a basket where the grass has run out of economic life. Partners cannot afford the equipment, so often in the search for animal feed takes a long time to slash.

3. There is no cow dung drain, which causes odor and the cowshed becomes dirty.

4. This cow dung has not been processed as organic fertilizer which can provide additional income for farmers, so it needs the help of tools to process cow dung into organic fertilizer. Need to be given knowledge of marketing agricultural products so that farmers do not focus on the field.

\section{Solution}

The purpose of this program is to help partners "Karang Ayu and Karya Laksana" in terms of overcoming the problems faced related to business development. From the problems that have been identified, the solutions for solving the problems offered are:

1. Establishment and design of Bali cattle rearing management.

2. Preparation of work plans and socialization of Bali cattle rearing management programs.

3. Assist in the process of raising Bali cattle.

4. Procurement of some equipment that has been damaged such as sickles, baskets, shovels and buckets to facilitate the provision of cattle feed

5. Dissemination of digital marketing in the Covid-19 Era.

The stages of implementing the activities that have been planned can be described as follows. In this activity the team provided an explanation of good and proper cattle maintenance and feeding Bali Cattle Feed. The form of science and technology given to partner 1 (Coral Ayu Livestock Group) and partner 2 (Karya Livestock Farmers Group), in general:

a) Provide an understanding of Bali cattle rearing management through intensive socialization of

b) PPPUD activities to equalize perceptions and strengthen partner group institutions.

c) Provide cattle rearing management training to the community, especially to partner groups. So far, there is no public knowledge, especially on marketing issues related to Natural Resources Cultural Tourism [9, 11].

d) Provide training on making organic fertilizer in partner groups from cow dung.

e) Provide socialization to partner groups related to the importance of packaging and labeling of organic fertilizer products produced.

f) Provide socialization to partner groups related to the system of management and arrangement of natural resources as well as complementing natural resource facilities and the preparation of governance and management of natural resource tourism.

g) Provide materials, socialization, and understanding of natural resource tourism supporting facilities, English, handicrafts, monitoring activities and promotional activities. Provide an understanding of the importance of promoting products produced through provincial level events even $[10,13]$ 

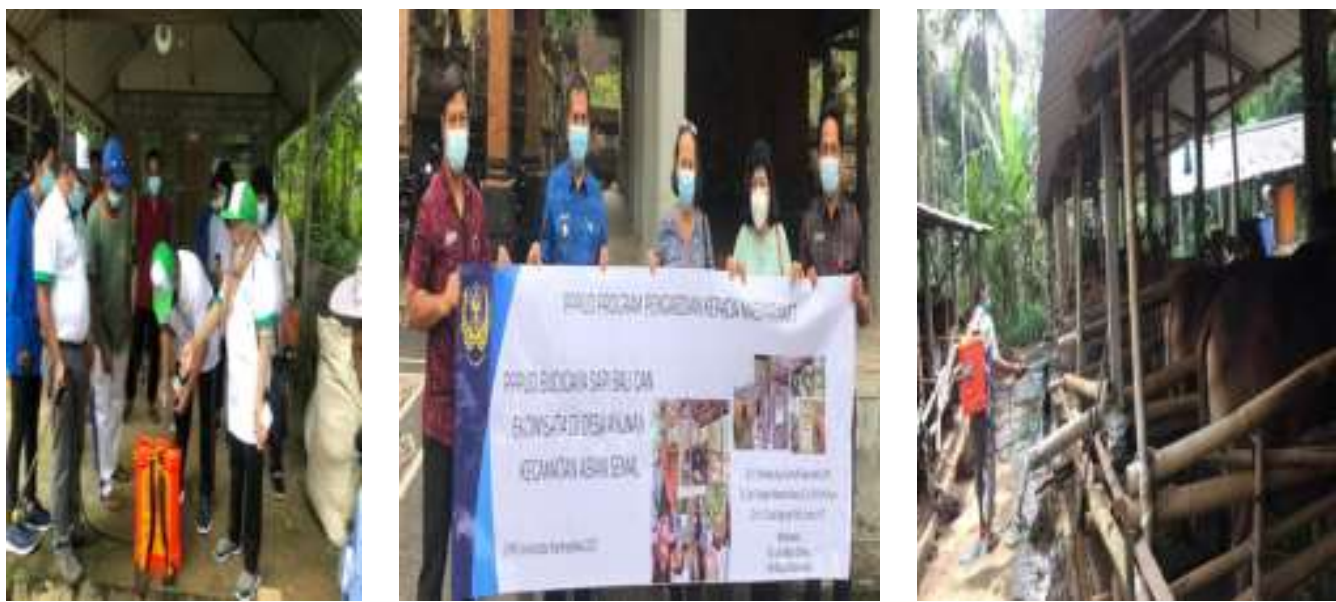

Figure 2. Fumigation activity in cow shed

\section{Conclusion}

Bali cattle cultivation in the swing village has been implemented well, almost $95 \%$ of farmers are responsible for their livestock. And the management of cow dung by drying has been done, farmers focus on production but have not been able to market their fertilizer products. It is suggested by farmers that the implementation of this PKM can continue, especially in the field of marketing, because farmers have not been able to sell their products, only able to process and produce fertilizers.

\section{Acknowledgment}

The author would like to thank all those who have helped in completing this research

\section{Reference}

[1] Monografi Dan Data Kependudukan Desa Ayunan Kecamatan Abiansemal, Badung 2019

[2] Astiti, Nmagr; Rukmini, Ni Ketut Sri Dan Ni Ketut Mardewi. 2018. Teknik Budidaya Sapi Bali Di Desa Selat Badung. Laporan Pkm Institusi Universitas Warmadewa Denpasar

[3] Profil Kemlompok Tani Ternak Karang Ayu. 2018. Desa Ayunan. Kecamatan Abian Semal Kabupaten Badung.

[4] Astiti, Ni Made Ayu Gemuh Rasa Astiti. 2018. Pengantar Ilmu Peternakan. Warmadewa University Press. Denpasar.

[5] Astiti, Ni Made Ayu Gemuh Rasa. 2018. Sapi Bali Dan Pemasarannya. Warmadewa University Press Denpasar.

[6] Annonimous. 2008.Teknologi, Alat Dan Mesin Peternakan. Modul Diklat Teknis Substantif Peternakan Tingkat Dasar. Teknologi Peternakan Dan Alsin.Dinas Peternakan Propinsi Jawa Barat.

[7] Astiti, NMAGR, Putri Risa Andriani Dan NKS Rukmini. 2020. Ateknik Pemasaran Sapi Bali Di Kelompok Ternak Sari Sedana. Laporan Pkm Institusi Universitas Wamadewa, Denpasar.

[8] Astiti, Nmagr, Nks Rukmini Dan Putri Risa Andriani. 2019. Utilization of Fermented Rice Strow for Bali Cowfeed in The Sari Lestari. Prociding Of $2^{\text {nd }}$ Warmadewa Research and Development Seminar. Wards Page 126-130.

[9] Astiti, N. M. A. G. R. (2018). Sapi Bali Dan Pemasarannya. Jayapangus Press Books, I-106.

[10] Darmawi, D. (2011). Pendapatan Usaha Pemeliharaan Sapi Bali Di Kabupaten Muaro Jambi. Jurnal Ilmiah Ilmu-Ilmu Peternakan, 14-22.

[11] Sampurna, I. P., \& Suatha, I. K. (2010). Pertumbuhan Alometri Dimensi Panjang Dan Lingkar Tubuh Sapi Bali Jantan. Jurnal Veteriner, 11(1), 46-51.

[12] Widagdyo, K. G. (2017). Pemasaran, Daya Tarik Ekowisata, Dan Minat Berkunjung Wisatawan. Esensi: Jurnal Bisnis Dan Manajemen, 7(2), 261-276. 
[13] Aryunda, H. (2011). Dampak Ekonomi Pengembangan Kawasan Ekowisata Kepulauan Seribu. Jurnal Perencanaan Wilayah Dan Kota, 22(1), 1-16.

[14] Oktavianie, D. A. (2018). Breeding Engineering, Producing and Marketing Laboratory Mice (Mus Musculus) As Animal Research. Journal Of Innovation and Applied Technology, 4(2), 727-730.

[15] Sardjadidjai, R., \& Sitorus, S. R. P. (1995). Transmigration Program with Animal Ilushandry Model in Indonesia. Buletin Peternakan= Bulletin of Animal Science (Special Edition), (1995).

[16] Sidebang, A. A., Sembiring, I., Mirwandhono, E., \& Tafsin, M. (2017). Marketing Efficiency Analysis of Beef Cattle in Animal Market Suka Village Tigapanah Subdistrict Karo District. Jurnal Peternakan Integratif, 5(1).

[17] Azuar Juliandi, dkk, Metodologi Penelitian Bisnis, Medan: UMSU Press, 2014.

[18] Sugiyono, (2014) Metode Penelitian Pendidikan Pendekatan Kuantitatif, Bandung: Alfabeta, 123. 